DOI: 10.12731/2227-930X-2017-4-26-52

УДК 377.1

\title{
НОВЫЙ ВЗГЛЯД НА ОЦЕНКУ КАЧЕСТВА ЕСТЕСТВЕННОНАУЧНОЙ И ПРОФЕССИОНАЛЬНОЙ ПОДГОТОВКИ СТУДЕНТОВ ОРГАНИЗАЦИЙ СРЕДНЕГО ПРОФЕССИОНАЛЬНОГО ОБРАЗОВАНИЯ
}

\section{Камалеева А.Р., Грузкова С.Ю., Шигапова Н.В.}

В статье анализируется проблема отбора новых адаптированных обучающих технологий и методов оченивания интегративных качеств студентов в рамках требований новых образовательных стандартов среднего профессионального образования. Рассматривается точка зрения отечественных и зарубежных ученых на понимание термина «педагогическая технология». Отмечаются методологические требования к педагогическим технологиям. Приводится структура технологии обучения. Описываются этапь освоения педагогической технологии и уровни оченки ее эффективности без использования и при использовании информационно-коммуникационных технологий. Подробно рассматриваются: методика формирования универсальных учебных действий, которая применяется для оченки результата учебной деятельности у первокурсников, а также в старших классах общееобразовательной школь; сквозная технология, которая ориентирует на оченку степени сформированности у студентов общих и профессиональных компетенций, в форме числовых характеристик, начиная со второго и последующих курсах обучения в СПО; метод пролонгированного оченивания с помощьюю балльно-рейтинговой системы, позволяющий пошагово отслеживать у обучающихся уровень знаний, умений, сформированности того или иного практического опьта, готовности и способности выполнять ту или иную деятельность на протяжении всего периода изучения соответствующей учебной дисииплины; методика 
расчета абсолютной успеваемости, а также показателя полного усвоения учебного материала.

Цель - анализ методов и педагогических технологий, позволяющих получить более объективную количественную оценку результатов обучения и успеваемости студентов.

Метод или методология проведения работы: в статье использовался теоретический анализ методов и технологий применяемых для оченивания результатов обучения студентов.

Результаты: Описано применение педагогических технологий и методов определения числовых характеристик интегративных качеств студентов с учетом специфики учебного курса.

Область применения результатов: полученные результать будут полезны педагогам дисииплин естественнонаучного и профессионального иикла в системе среднего профессионального образования.

Ключевые слова: студенты СПО; педагогическая технология; результаты обучения; числовые характеристики результатов обучения.

\section{THE NEW VIEW AT THE QUALITY OF ASSESSMENT OF NATURAL SCIENCE AND VOCATIONAL TRAINING OF STUDENTS OF SECONDARY VOCATIONAL EDUCATION INSTITUTIONS}

\section{Kamaleeva A.R., Gruzkova S.Yu., Shigapova N.V.}

This article analyzes the problem of selection of new adapted training technologies and assessment methods of students 'integrative qualities within the frames of requirements of the new educational standards of secondary vocational education. We consider the point of view of domestic and foreign scientists at the understanding of the term «educational technology». Methodological requirements of teaching techniques are also mentioned in this article. We present the structure of teaching technologies; describe the stages of the educational technolo- 
gy development and levels of evaluating its effectiveness with using and without using of information and communication technologies. This article also considers the next aspects: method of formation of universal educational actions, which is used to evaluate the results of educational activity of first-year students as well as high school students; end-to-end technology, that focuses on the assessment of the degree of formation of the students of general and professional competences in the form of numerical characteristics and starts from the second year of studying in VEI; prolongate evaluation method, that uses the score-rating system and allows to track students' level of knowledge, skills and formation of one or another experience step by step as well as track the willingness and ability to do one or another activity for the entire period of studying the relevant discipline; method of calculating of the absolute studying progress as well as a total index of learning material.

Purpose - the analysis of the methods and pedagogical technologies allowing to receive more objective quantitative assessment of results of training and progress of students.

Methodology: In article the theoretical analysis of methods and technologies of the results of training of students applied to estimation was used.

Results: Use of pedagogical technologies and methods of definition of numerical characteristics of integrative qualities of students taking into account specifics of a training course is described.

Practical implications: the received results will be useful to teachers of disciplines of a natural-science and professional cycle in system of secondary professional education.

Keywords: Vocational Education Institute (VEI) students; pedagogical technology; teaching results; numerical characteristics of teaching results.

\section{Topicality}

The main contradiction of modern education system is contradiction between the rapid rate of increment of natural science knowledge in the modern world and limited abilities of its learning, what dictates 
the need to focus on creating of basic conditions for realization of "teacher-student" interaction. In this interaction teaching forms the student's willingness for conscious perception of training information, actuates intellectual activity and develops creativity of students. The key condition of successful training of future specialists is active using of new adapted learning technologies. In turn, students' progress can act as individual characteristic of effectiveness of choice of one or another training technology for one student or generalizing characteristic for the group of students. Obviously, selection of tools for ensuring of the more possible impartial assessment of knowledge, abilities and practical skills of students, who studies the criteria, what is shown in the education system, is significant problem as well as selection of training technology.

In this connection, the material of this article is devoted to analysis of technologies that allow to conduct the qualitative assessment of educational material, assimilated by students.

\section{Materials and methods of research}

K.D. Ushinskiy pointed that every nation has its own national education system, which depends on culture, lifestyle, religion and values. Scientific field, related to terms of "training technology" and "pedagogical technology", indicating the planning and development of learning processes for solving the given didactic (pedagogic) tasks, has began to develop in the western pedagogy in the middle of the twentieth century. In the domestic science the «pedagogical technology» category has recently appeared and it is understood in different ways by different authors and does not have definite interpretation (see Table. 1). Western practice, unlike Russia, distinguishes the two approaches to the definition of "pedagogical technology." First approach (narrow owner) is associated with using of different equipment in pedagogical process; second approach (the general one) is based on the integrated using of technical and human resources.

Also, in the concept of "learning technology" two layers are distinguished: science or complex of information system required to teach- 
er for the implementation of one or another learning process and the learning process itself, its organization, structure and support. Therefore, pedagogical technology is considered from two attitudes:

- research (theoretical) attitude, which is based on definition of complex of forms, methods, techniques, methodology and means of transmission of social experience for the most optimal achievement of educational goals;

- practice-oriented attitude, providing the most appropriate sequence of social and educational activity, allowing to achieve the expected rational result in a specific learning situation.

Table 1.

Interpretation of term «pedagogical technology» by domestic and foreign authors

\begin{tabular}{|l|l|}
\hline \multicolumn{1}{|c|}{ Domestic authors } & \multicolumn{1}{c|}{ Foreign authors } \\
\hline $\begin{array}{l}\text { Complex of psychological } \\
\text { and pedagogical attitudes } \\
\text { (B.T. Lihachyov) }\end{array}$ & $\begin{array}{l}\text { Composite procedural part of didactic system } \\
\text { (M.A. Choshanov) }\end{array}$ \\
\hline $\begin{array}{l}\text { Skill, mastery, ability, } \\
\text { complex of methods of pro- } \\
\text { cessing and modification of } \\
\text { condition (B.M. Shepel) }\end{array}$ & $\begin{array}{l}\text { Meaning of «pedagogical technology» is concludes } \\
\text { in using of inventions, industrial devices and pro- } \\
\text { cess in education field, which are becoming a part } \\
\text { of time technology (M. Clark) }\end{array}$ \\
\hline $\begin{array}{l}\text { Description of process of } \\
\text { achievement of planned } \\
\text { results of studying } \\
\text { (I.P. Volkov) }\end{array}$ & $\begin{array}{l}\text { It is not only a complex of equipment and studying } \\
\text { materials but also a method of organization, image } \\
\text { of thoughts about materials, people, institutions, } \\
\text { models and «man-machine» systems (D. Fynn) }\end{array}$ \\
\hline $\begin{array}{l}\text { Substantial technique of real- } \\
\text { ization of education process } \\
\text { (V.P. Bespal'ko) }\end{array}$ & $\begin{array}{l}\text { Ability of using of different means of assignment of } \\
\text { information (F. Percival; G. Ellington) }\end{array}$ \\
\hline $\begin{array}{l}\text { Model of mutual pedagogical } \\
\text { activity (B. M. Monahov) } \\
\text { and others. }\end{array}$ & $\begin{array}{l}\text { Area of research and practice, having relations } \\
\text { to every aspects of pedagogic system's organiza- } \\
\text { tion and procedure of distribution of sources for } \\
\text { achievement of specific and potentially reproducing } \\
\text { results (P.D. Mitchell) and others. }\end{array}$ \\
\hline
\end{tabular}

Majority of researchers agree that the concept of "pedagogical technology" can be considered as systematic method of creation, application and determination of the whole process of teaching and 
learning, subject to technical and human sources, as well as their interaction, which concentrates on the optimization of methods and forms of education [1].

It is necessary to mention that any pedagogical technology must satisfy the basic methodological requirements, such as conceptual, systematic, efficiency, reproducibility, controllability (see Figure 1) [2].

\begin{tabular}{|c|c|c|c|c|}
\hline Conceptual & Systematic & Efficiency & Reproducibility & Controlability \\
\hline 1 & 1 & 1 & 1 & 1 \\
\hline $\begin{array}{l}\text { Pedagogical technology } \\
\text { should be based on a } \\
\text { specific scientific } \\
\text { concept, containing } \\
\text { philosophical, } \\
\text { psychological, didactic, } \\
\text { social and pedagogical } \\
\text { grounding for achieving }\end{array}$ & $\begin{array}{l}\text { Pedagogical } \\
\text { technology must } \\
\text { have the character- } \\
\text { ristics of a system: } \\
\text { - logic of the } \\
\text { process; - intercon- } \\
\text { nection of all process } \\
\text { systems; - integrity }\end{array}$ & $\begin{array}{l}\text { Orientation of } \\
\text { pedagogical } \\
\text { technology to } \\
\text { achievement } \\
\text { (cost-optimal) of } \\
\text { professional } \\
\text { standard } \\
\text { requirements }\end{array}$ & $\begin{array}{l}\text { The possibility of } \\
\text { reproducing of } \\
\text { pedagogical } \\
\text { technology in the } \\
\text { same type of } \\
\text { educational } \\
\text { institutions }\end{array}$ & $\begin{array}{l}\text { The possibility } \\
\text { of varying } \\
\text { means and } \\
\text { methods for } \\
\text { achieving } \\
\text { results }\end{array}$ \\
\hline
\end{tabular}

Fig. 1. Methodological requirements for pedagogical technology

In addition, learning technology as a system category should be focused on the didactic application of scientific knowledge, scientific approaches to the analysis and organization of educational process in view of the empirical innovation and orientation at achieving of the expected results in the development of the personality of student in accordance with a certain structure (see Figure 2) [3].

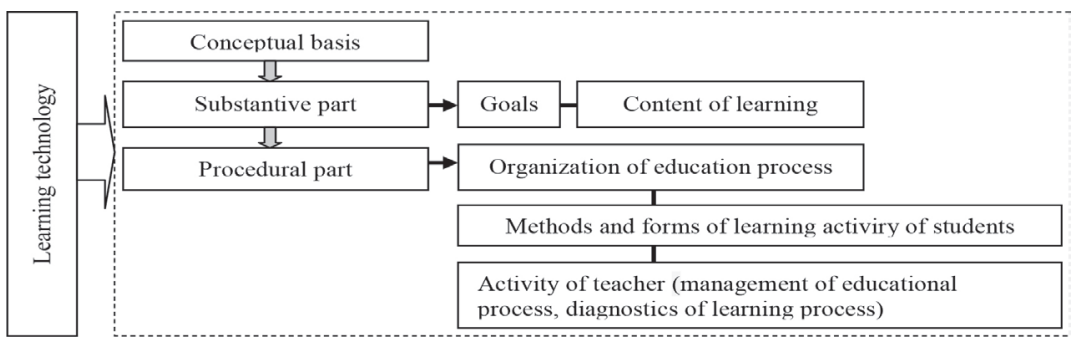

Fig. 2. Structure of learning technology

Learning technology suggests, that attainment of the teacher of the technological level of the educational process and design of this project significantly increases the role of student and opens the new horizons for the development of his creativity. At the same time, for teacher as highly 
qualified specialists it is necessary to create conditions of studying and do all the best to this mutual process (teaching person - learner) for both sides would be absolutely equal in the choice of methods and means of this development, and the main function of the teacher is to teach to learn - not learn to do that teacher asks, as it happens in reality [4].

The effectiveness of innovative educational technologies is determined by the ratio of the achieved results to the expenditure of time and sources (material, technical, informational and human sources) [5]. With regard to $\boldsymbol{e}$ criteria of efficiency of pedagogical techniques, they can be identified even at the design stage of the learning process in the next forms:

- division of the learning process into stages, phases, operations, procedures;

- algorithmic and technological sequence of applying of the developed mechanism of the implementation of education discipline, based on the internal logics of functioning with a precise order of actions and operations and providing feedback for all procedures;

- availability of evaluation and management criteria, including indicator of selection of unit of digestion unit selection, comparison with the standard, selection of correction method, extent of achievement of goals.

In the stage of functioning each criteria is characterized by certain indicators:

- informational content and comprehensibility of learning material;

- adequacy of the methods of learning of goals and content;

- validity in the perceptive, Gnostic, logical, evaluation and motivational aspects, variety and variability.

The procedure of mastering of pedagogical technology consists of three stages as follows theoretical, practical and analytical (see Figure 3) [6]. Accordingly, the procedure for assessment of the effectiveness of pedagogical technologies also includes three levels: theoretical, practical and generalized level. In the case of using of informational and communicational technologies in the educational process, the procedure of assessment of their effectiveness is slightly different and it is 
concretized in depending on the technical equipment of the educational institution [7], and also consists of four levels: theoretical, practical, generalizing and preparatory level.

Innovational methods of assessment of the results of training allow to obtain efficient data of the level of learning of the educational material by the students for the teacher, and for the learners - to understand more clearly their achievements and deficiency, adjust their own activity, etc.

\begin{tabular}{|c|l|}
\hline \multicolumn{1}{|c|}{$\begin{array}{c}\text { The levels of its assessment with- } \\
\text { out using of informational and } \\
\text { communicational technologies }\end{array}$} \\
\hline \multicolumn{1}{|c|}{$\begin{array}{l}\text { 1st } \\
\text { level } \\
\text { Theo- } \\
\text { retical } \\
\text { technology assessment } \\
\text { at the selection stage, } \\
\text { - the correlation } \\
\text { of technology and } \\
\text { specific pedagogical } \\
\text { conditions (teacher's } \\
\text { assessment of the } \\
\text { effectiveness of peda- } \\
\text { gogical technology for } \\
\text { teaching in the studied } \\
\text { disciplines) }\end{array}$} \\
\hline $\begin{array}{c}\text { 2nd } \\
\text { level } \\
\text { Practi- } \\
\text { cal }\end{array}$ & $\begin{array}{l}\text { - the teacher's eval- } \\
\text { uation of the results } \\
\text { and costs of the ped- } \\
\text { agogical technology } \\
\text { as a result of the using } \\
\text { of statistical data, its } \\
\text { mathematical pro- } \\
\text { cessing as well as the } \\
\text { conclusion about its } \\
\text { effectiveness through } \\
\text { monitoring and mea- } \\
\text { suring means }\end{array}$ \\
\hline $\begin{array}{c}\text { 3rd } \\
\text { Gevel } \\
\text { alized }\end{array}$ & $\begin{array}{l}\text { - generalization of the } \\
\text { teacher's experience, } \\
\text { - analysis of his tech- } \\
\text { nological activities, } \\
\text { - comparison of } \\
\text { technological activity } \\
\text { results with traditional } \\
\text { training }\end{array}$ \\
\hline
\end{tabular}

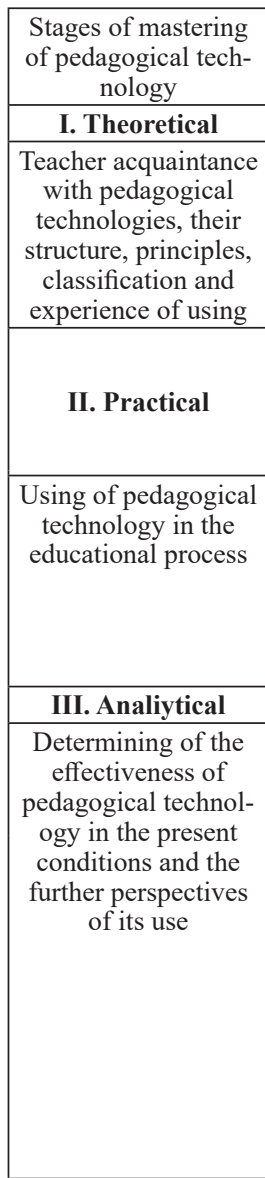

The levels of its assessment with using of informational and communicational technologies

- the teacher chooses appropriate informational and communicational technologies, - willingness of the teachers to using given technologies or to online teaching, - if it's necessary, the participation of teachers in retraining and advanced training - development of technological learning environment, - technical and academic support for students, studying online

- teacher's assessment of the effectiveness of the applied informational and communicational technologies (using software tools (shell) of such systems as: digital training tests, digital assessment tests, digital practical work, virtual laboratory work, etc.).

- generalization of the 4 th teacher's experience, - analysis of his technological activity

3rd

level Practical alized

Fig. 3. Stages of mastering of pedagogical technology and the levels of its assessment with or without using of informational and communicational technologies 
This is especially topical in the context of the transition of the national education system to the new educational standards and competences, as a result of education. In this case, educational technologies should act as a way of forming of competencies, and evaluation means should act as a tool of proving of achievement of the announced results of education.

As practice shows, part of the teachers of natural science disciplines in institutions of secondary vocational education in the process of transition to educational standards of the third generation (FSES SVE and SVE 3+) use the method of forming universal learning activities as a result of training activities of first-year students, which is used in high schools of comprehensive school. They believe that universal learning actions are the basis for selection and structuring the content of the educational methods, methodics, forms of education, and also the construction of integral teaching and educational process [8].

Mastering of universal learning actions by the students of the first course, taking place in the context of studying of natural science subjects, leads to the formation of these students to learn new knowledge, skills and abilities, including the independent organization of the learning process (i.e. the ability to learn) independently. This ability is ensured by the fact that universal learning actions considered as generalized methods of action [9], opens the possibility for students to broadly orient themselves in different subject areas as well as in the process of the learning activity itself, including realization of its goals orientation, along with value and semantic and operational characteristics. Thus, the achievement of the ability to learn implies full-fledged mastery of all the components of educational activity, including: educational motives; educational goal; educational task; training activities and operations (orientation, material transformation, monitoring and evaluation).

Most types of training activities are classified in blocks: personality universal educational activities, regulatory actions, volitional self-regulation, cognitive universal actions, universal cognitive actions, communicative actions (see Table 2). 
Practice shows that the majority of teachers consider it necessary to start forming competencies among students from the first days of their education in the system of vocational education, despite the fact that, in accordance with the standards of third generation SVE, the teachers are focused on the formation of general and professional student's competencies only from the second year.

The procedure of assessment of competencies in practice causes certain difficulties for teachers. A successful solution of the problem of assessment of learning results in the form of competencies, in our opinion, is the end-to-end technology suggested by the teacher and experimenter O.B. Russkova [10].

Table 2.

Learning actions of proper educational activity

\begin{tabular}{|l|l|}
\hline \multicolumn{1}{|c|}{ Block } & \multicolumn{1}{c|}{ Universal learning actions } \\
\hline $\begin{array}{l}\text { Block of per- } \\
\text { sonal universal } \\
\text { learning actions }\end{array}$ & $\begin{array}{l}\text { Actions of sense and moral and ethical evaluation, realized on } \\
\text { the basis of value and semantic orientation of students, as well as } \\
\text { orientation in social roles and interpersonal relationships. }\end{array}$ \\
\hline $\begin{array}{l}\text { Block of } \\
\text { regulatory } \\
\text { actions }\end{array}$ & $\begin{array}{l}\text { Actions, ensuring the organization of educational activities by } \\
\text { the students }\end{array}$ \\
\cline { 2 - 3 } & $\begin{array}{l}\text { goal-setting (setting a learning task); } \\
\text { planning (determining of sequence of intermediate goals with } \\
\text { thecount the final result); } \\
\text { making plan and sequence of actions; } \\
\text { control (in the form of a comparison of method of action and } \\
\text { its result with a specified standard); } \\
\text { correction (introduction of necessary additions and adjust- } \\
\text { ments to the plan, and method of action in case of divergence of } \\
\text { the standard, the real action and its product); } \\
\text { assessment (highlighting and comprehension of what has } \\
\text { been learned and what is still has to be learned, awareness of } \\
\text { quality and level of mastery by students). }\end{array}$ \\
\hline $\begin{array}{l}\text { Block of volition } \\
\text { self-regulation }\end{array}$ & $\begin{array}{l}\text { ability to mobilize strength and energy, } \\
\text { motivational conflict), to overcome obstacles. }\end{array}$ \\
\hline
\end{tabular}


The end of a table 2.

\begin{tabular}{|c|c|}
\hline $\begin{array}{l}\text { Block of uni- } \\
\text { versal actions of } \\
\text { cognitive orien- } \\
\text { tation }\end{array}$ & $\begin{array}{l}\text { general educational activities (including sign-symbolic and } \\
\text { logical actions); } \\
\text { actions of setting and solving problems (problem formulation } \\
\text { and independent creation of ways of solving problems of cre- } \\
\text { ative and exploratory nature). }\end{array}$ \\
\hline $\begin{array}{l}\text { Block of uni- } \\
\text { versal logical } \\
\text { actions }\end{array}$ & $\begin{array}{l}\text { analysis of objects with the purpose of distinguishing features } \\
\text { (significant/insignificant); } \\
\text { synthesis (compilation of the whole from different parts, in- } \\
\text { cluding independent completion, replenishment of missing com- } \\
\text { ponents); } \\
\text { selection of basis and criteria (for comparison, seriation, clas- } \\
\text { sification of objects); } \\
\text { class to the concepts, selection consequences; } \\
\text { establishment of causal relationships (construction of a logi- } \\
\text { chain of reasoning, arguments); }\end{array}$ \\
\hline \multirow[t]{2}{*}{$\begin{array}{l}\text { Block of } \\
\text { communicative } \\
\text { actions }\end{array}$} & $\begin{array}{l}\text { Actions, which ensure a social competence and consideration of } \\
\text { other people, of a partner in communication or work, ability to lis- } \\
\text { ten and engage in dialogue, participate in a collective discussion } \\
\text { of problems, ability to integrate into a group of people of the same } \\
\text { age and ability to build productive interaction with peers and adults }\end{array}$ \\
\hline & $\begin{array}{l}\text { planning of educational cooperation with the teacher and peers } \\
\text { (detection of the purpose, functions of participants, ways of inter- } \\
\text { action); } \\
\text { arrangement of questions (initiative cooperation in the search- } \\
\text { ing and collection of information); } \\
\text { conflict resolution (detection of problem identification, search- } \\
\text { ing and assessment of alternative methods of conflict resolution, } \\
\text { making decision and its implementation); } \\
\text { control of the partner's behavior (control, correction, assess- } \\
\text { ment of actions of the partner); } \\
\text { ability to express your thoughts with sufficient completeness } \\
\text { and accuracy in accordance with the tasks and conditions of com- } \\
\text { munication; } \\
\text { grasp of monological and dialogical forms of speech in ac- } \\
\text { cordance with the grammatical and syntactic norms of the native } \\
\text { language. }\end{array}$ \\
\hline
\end{tabular}

This technology focuses on determining of the result of learning (i.e., student progress) in the form of numerical characteristics, since 
the level of formation and subsequent development of students in certain competences (in accordance with the requirements for the results of the development of educational programs FSES and the requirements of employers) most fully defined through a numerical index in qualitative aspects.

Valuation specificity of the end-to-end technology of assessment of learning results proposed by O.B. Russkova, focuses on:

- detection of the coefficient of the semi-final form of attestation $\tau$;

- consideration of the type of final certification in the discipline test / examination (i.e., $\tau=1$ - pass or $\tau=0$ - fail). If, examination is provided for this discipline in the end of the semester, $\tau$ will be equal to the mark received by the student at the exam in accordance with the requirements for the structure of the main educational programs of FSES SVE3 for each discipline and the list of competences (Cultural, Generally vocational and Vocational competences), generated within the limits of tone or another discipline.

Thus, any teaching discipline has its own weight, expressed in hours allocated for the studying of the discipline according to the training plan and it is expressed in laboriousness $-T$. Assessment by teachers takes place on the basis of developed complex assessment tools (CAT), which can include control and measurement materials (CMM), according to which a score is graded, as well as materials of the quality assessment of competence formation without of grading (at the qualification exam during studying a professional module).

Taking into account the fact that the same competence can be formed both at the first year of training and at the following years, it is necessary to determine the levels of assimilation of competencies $(\lambda)$ at each stage of its formation. At the same time, it is necessary to take into account that lecture and practical classes, conducted at the first year (at the first and second terms), give only the initial level of mastering competences. The fifth and sixth levels (at the third year) can be reached during the fulfillment of production practice or graduation qualification work by students. 
Thus, having a complex of factors reflecting the level of mastering of one or another competence, there is can obtain the formula for detection the dependence of the development of given competence on specific disciplines which have read during the process of mastering of various educational programs (see formula (1)).

$$
W=\frac{\sum_{i=1}^{k} \tau_{i} \cdot \lambda_{i} \cdot T_{i}}{100 * k}
$$

where: $k-$ is the number of terms during which one particular discipline is taught;

$T i$ - laboriousness (number of hours in the curriculum);

$\lambda i$ - the level of mastering of the competence;

$\tau i$ - coefficient of the term form of attestation.

The consistent application of the formula (1) for each student will make it possible to obtain a more qualitative assessment of the formation of one or another competence for the given disciplines during the entire learning process.

\section{Results and discussion}

As an example, there will be considered the development of one of the vocational competencies (VC 1.1) of students studying the multidisciplinary course (MDC.01.01) "Technology of forming of automatic control systems, typical technological processes, measuring instruments and simple mechatronic systems" in specialty 220703 "Automation of technological processes and productions". According to the educational standard, this competence provides for the ability to "analyze the efficiency of measuring instruments and automation equipment" and begins to form, in accordance with the through technology, from the first year of the studying of general subjects (physics, chemistry, biology, mathematics), it continues in studying general professional disciplines (engineering graphics, technical mechanics, labor safety, life safety, materials science, electrical engineering measurements, electrical machines) and it is consolidated in the study of MDC.01.01. [10]. Table 3 presents a fragment of the «sequential for- 
mation» VC 1.1. during the entire period of studying the disciplines that affect its formation and development.

Table 3.

Formation of «PC 1.1. Conduct the analysis of the efficiency of measuring instruments and automation means» during the entire period of study of disciplines that affect its development

\begin{tabular}{|c|c|c|c|c|c|c|c|c|}
\hline \multirow[b]{2}{*}{ № } & \multirow[b]{2}{*}{$\begin{array}{l}\text { Disciplines and models, } \\
\text { forming the VC } 1.1 \text {. }\end{array}$} & \multicolumn{7}{|c|}{ Parameter of competence } \\
\hline & & Grade & $\tau$ & $\begin{array}{c}\text { Term of } \\
\text { studying }\end{array}$ & $\lambda$ & $k$ & $\begin{array}{l}\text { Number } \\
\text { of hours at } \\
\text { studying } \\
\text { plan } \\
T \\
T\end{array}$ & \begin{tabular}{|c|}
$\begin{array}{c}\text { Coefficient } \\
\text { of compe- } \\
\text { tence devel- } \\
\text { opment } \\
W\end{array}$ \\
\end{tabular} \\
\hline 1 & Physics & 4 & 4 & 1,2 & 1 & 2 & 254 & 5,08 \\
\hline 2 & Engineering graphics & 4 & 4 & 3,4 & 2 & 2 & 131 & 5,24 \\
\hline 3 & Technical mechanics & 3 & 3 & 3,4 & 3 & 2 & 94 & 4,23 \\
\hline 4 & Labor safety & pass & 1 & 7 & 3 & 1 & 65 & 1,95 \\
\hline 5 & Life safety & pass & 1 & $3,4,5,6$ & 4 & 4 & 102 & 1,02 \\
\hline 6 & Materials science & 4 & 4 & 3,4 & 3 & 2 & 101 & 6,06 \\
\hline 7 & Electrical engineering measurements & 3 & 3 & 3,4 & 4 & 2 & 131 & 7,86 \\
\hline 8 & Electrical machines & 3 & 3 & 3,4 & 4 & 2 & 121 & 7,26 \\
\hline 9 & $\begin{array}{l}\text { MDC. } 01.01 \text { «Technology of forming of } \\
\text { automatic control systems, typical tech- } \\
\text { nological processes, measuring instru- } \\
\text { ments and simple mechatronic systems» }\end{array}$ & 4 & 4 & 5,6 & 6 & 2 & 137 & 16,44 \\
\hline
\end{tabular}

According to the data presented in Table 3, the dependence of the coefficient of development of competence (W) by the results of studying one or another academic discipline or course can be seen graphically in Figure. 4.

It should be mentioned, that the coefficient of competence development $-W$ (Figure 4) reflects the part which one or another discipline or multidisciplinary course is contributed in the forming of general level of formation, in our case, the vocational competence VC 1.1.

It can be seen From Fig. 4 that, according to the disciplines of "Life safety" and "Labor safety, the competence development coefficient has the lowest indicator. However, this does not mean that these disciplines drop the level of competence development. Rather, it shows that the contribution of these disciplines to the formation of the $\mathrm{VC} 1.1 \mathrm{a}$ 
smaller in compare to other disciplines, such as physics, engineering graphics, technical mechanics, etc.

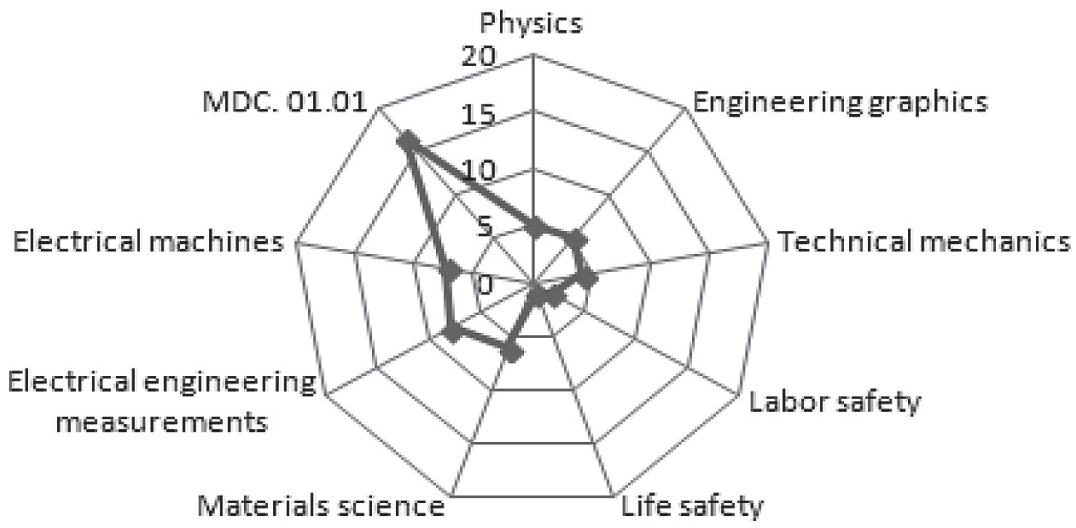

Fig. 4. Coefficient of development of competence (W) by the results of studying one or another academic discipline or course

It is possible to calculate the index of the development coefficient of any competencies in other specialties, as well as in training groups and courses, which allows to consider the development of one or other competencies for each student individually [10], applying the formula (1) and the table 3 in a similar way. This analysis for each student of a certain group or for a group of students of a certain course (for example, according to the average score of the group) gives an objective assessment of the quality of teaching of various disciplines from the point of forming competencies.

Along with the considered end-to-end technology of assessment of the results of students' learning in the form of competencies, method of prolonged assessment with the help of rating system, especially with active using of elements of informational and communicational technology, can be considered as successful method in solution of the problem of qualitative and impartial assessment of knowledge and integrative qualities of students [11].

The method of prolonged assessment, as well as end-to-end technology, is focused on the detectioning of numerical characteristics. How- 
ever, unlike the first one, which calculates the numerical index of the development of interested competence in the studying of one or another discipline or multidisciplinary course, the method of prolonged assessment allows to track the level of knowledge, skills, the formation of one or another practical experience, willingness and ability to do one or another activity during the entire period of studying of the discipline or multidisciplinary course (at lectures, seminars, while doing laboratory work and other forms) step by step. Based on the results of the studied discipline or multidisciplinary course, the index of the student's progress rating in points is converted into a five-point system, and the index of knowledge quality also can be calculated, if it is necessary [12].

We will consider the using of the method of prolonged assessment in studying of the professional module "Control and metrological provision of tools and automation systems" [12]. The content of this module provides the studying of three interdisciplinary courses by the students: "MDC.01.01. "Technology of forming of automatic control systems, typical technological processes, measuring instruments and simple mechatronic systems", "MDC.01.02 Methods of implementing conventional and certification tests, metrological verifications of measuring instruments", "MDC.01.03. Theoretical basis of control and analysis of the functioning of automatic control systems". The module ends with the defense of the course papers.

For the purpose of more objective "assessment of the volume and level of mastering of one professional module by students, the teacher, before starting to teach, produces the initial «test» of residual knowledge (the entrance test) for students (based on the results of the studied general educational disciplines, as well as a number of general vocational disciplines). Further, during the course of studying, teacher brings (using Microsoft Office program) the results (in points) of the verification of the mastering of lecture material and seminars to the electronic database.

Testing the mastering of the lecture material can be realized by using the test tasks (of open and closed forms), be monitored at the seminars, during solution of estimated tasks (it is selected with differ- 
ent levels of difficulty and assessed by a different number of points, and at the beginning of the term test tasks can be graded from 0 to 3 points, and by the end of the term it can be graded to 5 points, as the study material increases their complex it increases as well)". As for the seminars, they "require to work seriously from the student, therefore, they should be assessed according to several parameters, for example, by the form of presentation of the material, clarity in explaining the principles and provisions, the volume and quality of the worked sources of information, the culture during discussing reports, etc. Laboratory and practical work are assessed by increased coefficient - in the range from 0 to 5 points - because they provide for active participation of the student and facilitate the mastering of several competences at once. Based on the results of each lesson, the maximum score received by a student in a group during doing a task is taken as the maximum (for each class or courses) [12, c. 77-78]. This approach makes it possible (in the opinion of O.V. Sofinskaya, a teacher and improver) to avoid understating or overstating of grades due to imperfections of the methodology or tasks that are inevitable in the period of formation of the system of monitoring and assessing to the quality of mastering the competences specified in the work program of the multidisciplinary course (see figure 5)".

Thus, "the rating is updated depending on the number of classes per week, as well as during bringing of regular student scores (points). Gain of additional rating points is possible with the current survey.

\begin{tabular}{|l|c|c|c|c|c|c|c|c|c|c|c|c|c|c|c|c|}
\hline $\begin{array}{l}\text { No of } \\
\text { student }\end{array}$ & $\begin{array}{c}\text { Initial } \\
\text { test }\end{array}$ & $\begin{array}{c}\text { Test } \\
1\end{array}$ & $\begin{array}{c}\text { Test } \\
2\end{array}$ & $\begin{array}{c}\text { Semi } \\
\text { nar } 1\end{array}$ & $\begin{array}{c}\text { Semi } \\
\text { nar 2 } 2\end{array}$ & $\begin{array}{c}\text { Semi } \\
\text { nar } 3\end{array}$ & $\begin{array}{c}\text { Prac } \\
\text { tice 1 }\end{array}$ & $\begin{array}{c}\text { Prac } \\
\text { tice } 2\end{array}$ & $\begin{array}{c}\text { Prac } \\
\text { ticen }\end{array}$ & $\begin{array}{c}\text { Test } \\
\text { n }\end{array}$ & $\begin{array}{c}\text { Lab. } \\
1\end{array}$ & $\begin{array}{c}\text { Lab. } \\
2\end{array}$ & $\begin{array}{c}\text { Lab. } \\
\text { n }\end{array}$ & $\begin{array}{c}\text { Test } \\
\text { n+1 }\end{array}$ & $\begin{array}{c}\text { Raiting, } \\
\text { grade }\end{array}$ & $\begin{array}{c}\text { Asses } \\
\text { sment }\end{array}$ \\
\hline 1 & 2 & 3 & 4 & 5 & 6 & 7 & 8 & 9 & 10 & 11 & 12 & 13 & 14 & 15 & 16 & 17 \\
\hline $\begin{array}{l}\text { Student } \\
1\end{array}$ & 1,7 & 3,8 & 2,0 & 3,0 & 3,7 & 4,2 & 4,5 & 2,5 & 2,3 & 3,3 & 3,0 & 3,0 & 2,8 & 1,0 & 41,1 & 3,3 \\
\hline $\begin{array}{l}\text { Student } \\
2\end{array}$ & 3,3 & 4,0 & 3,8 & 4,5 & 4,3 & 3,8 & 3,5 & 4,3 & 5,0 & 5,0 & 5,0 & 4,5 & 5,0 & 4,0 & 60,2 & 4,8 \\
\hline atc. & $\ldots$ & $\ldots$ & $\ldots$ & $\ldots$ & $\ldots$ & $\ldots$ & $\ldots$ & $\ldots$ & $\ldots$ & $\ldots$ & $\ldots$ & $\ldots$ & $\ldots$ & $\ldots$ & $\ldots$ & $\ldots$ \\
\hline
\end{tabular}

Fig. 5. Scheme of disciplinary rating of student's progress

Missed seminar, practical or laboratory work is processed and their results are also bringing in the rating table. In turn, the presence of 
gaps deprives the students of the opportunity to get score points during school hours. This will require an additional training. This perspective reduces the number of absenteeism of classes due to inadequate reasons during the semester by students, which allows to reduce the workload in the week of tests and provides with the opportunity to qualitatively prepare for a better defense to the student. ... In addition, the demonstration of the rating allows students to plan their activities, to correlate their success with the overall level of achievements of the group of students, independently monitor their academic progress" [13].

Assessment of learning results in the process of mastering of any professional module presupposes a qualification examination.

Speaking about the progress of students it should also be mentioned that in the Russian education system, the progress percent (absolute progress - Pabs.), calculated according to formula (2), is taken as the indicator of the complete mastering of the learning material in accordance with any taken teaching and assessment technology.

$$
y_{\text {absol. }}=\frac{N_{\text {five }}+N_{\text {four }}+N_{\text {three }}}{N_{\text {total }}} \cdot 100 \%
$$

where: $N_{\text {five }}-$ the number of student, receiving the «A» mark;

$N_{\text {four }}$ - the number of student, receiving the «B» mark;

$N_{\text {three }}-$ the number of student, receiving the «C» mark;

$N_{\text {total }}-$ common number of students.

Also, a refinement indicator of the complete assimilation of the learning material - the percentage of the quality of knowledge (Pqual.), determined by the formula (3) - is used everywhere.

$$
y_{\text {quality }}=\frac{N_{\text {five }}+N_{\text {four }}}{N_{\text {total }}} \cdot 100 \%
$$

Using the formula for calculating absolute academic progress (1) and the formula for the refinement indicator for the complete assimilation of the learning material (2), the final results of the students' mastery of all three multidisciplinary courses of the vocational mod- 
ule (VM) in the process of using the rating system for assessment of learning results are summarized in Table 4.

Table 4.

Indicators of the effectiveness of mastering of the vocational module "Control and metrological provision of tools and automation systems" by the students

\begin{tabular}{|l|c|c|c|c|}
\hline \multirow{2}{*}{$\begin{array}{c}\text { Indicators of the effectiveness } \\
\text { of mastering of the VM }\end{array}$} & \multicolumn{2}{|c|}{ Group 1 } & \multicolumn{2}{c|}{ Group 2 } \\
\cline { 2 - 5 } & $\begin{array}{c}\mathrm{P} \text { abs., } \\
\%\end{array}$ & $\begin{array}{c}\text { Pqual., } \\
\%\end{array}$ & $\begin{array}{c}\mathrm{P} \text { abs., } \\
\%\end{array}$ & $\begin{array}{c}\text { Pqual., } \\
\%\end{array}$ \\
\hline Initial test & 65,0 & 47,6 & 68,0 & 51,2 \\
\hline MDC 1 (I term. 2015z.) & 72,2 & 66,7 & 80,0 & 60,0 \\
\hline MDC 2 (II term. 20152.) & 72,2 & 66,7 & 80,0 & 80,0 \\
\hline MDC 3 (I term. 2016z.) & 66,7 & 55,6 & 75,0 & 60,0 \\
\hline Qualification project (II term. 20162.) & 77,8 & 66,7 & 78,0 & 70,0 \\
\hline
\end{tabular}

The data of Table 4 is graphically shown in Fig. 6 and Fig. 7.

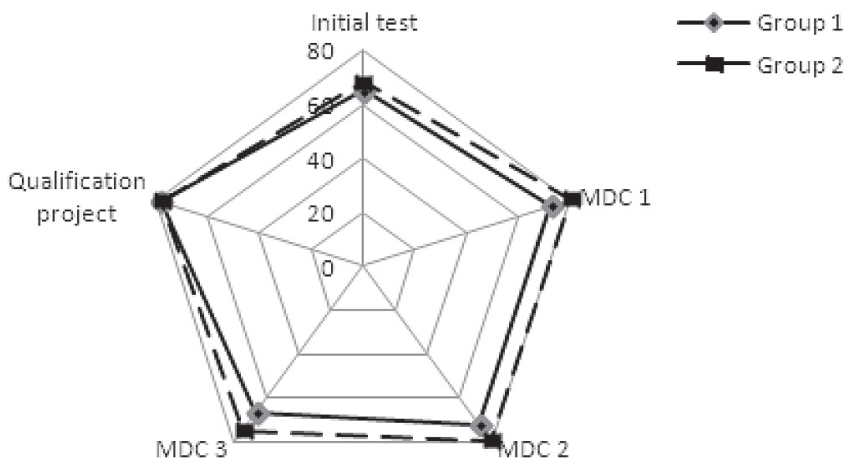

Fig. 6. Indicators of progress of mastering of the vocational module "Control and metrological provision of tools and automation systems" by the students

From the indicators of the quality of knowledge of students, presented in Table. 4 and in Fig. 6, it can be seen that the first two multidisciplinary courses have been mastered quite well by a group of students. This indicates that the students, using the obtained theoretical and practical skills, competences and abilities in the first and second years, and also taking into account the motivation for their future specialty, are able to use the measuring confidence equipment, calculate 
the parameters of typical scheme and structure, etc. The lower indicator of the quality of knowledge for MDC 3, in comparison with MDC 1 and MDC 2, can be substantiated by the fact that its content has a more economic, engineering character and its studying and understanding causes more difficulties for students. For this reason, for example, students should intensively study the purpose, structure and features of the programmed microprocessor controllers, their functional capabilities, tuning and control parts, etc.

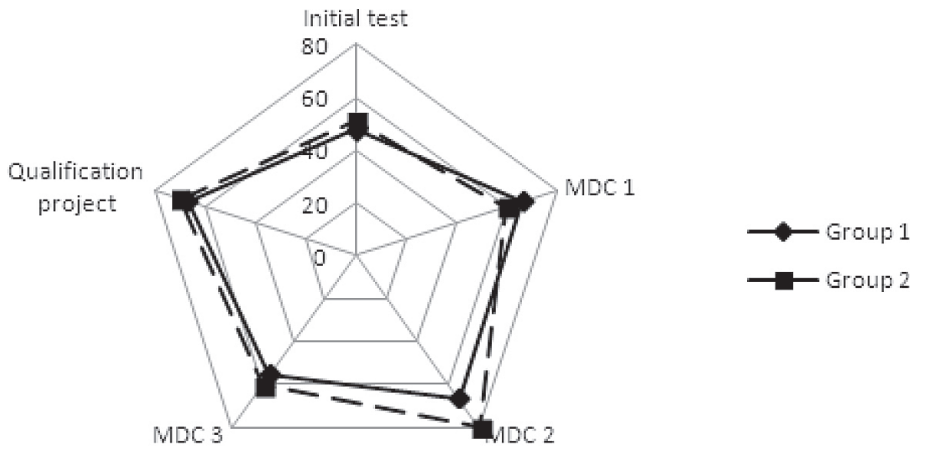

Fig. 7. Indicators of the quality of knowledge's of mastering of the vocational module "Control and metrological provision of tools and automation systems" by the students

However, upon completion of the studying of the vocational module, the students of the first and second groups successfully defended their qualification project, and each group approached quite large indicators of academic progress and quality on the average: group 1: $\mathrm{P}$ abs. $=77.8 \%$, Pqual. $=66.7 \%$;

group 2: $\mathrm{P}$ abs. $=78.0 \%, \mathrm{P} q u a l=70.0 \%$;

The received data indicates that application of the acting system of assessment of learning results with elements of informational and communicational technology has a positive influence on increasing of the effectiveness (absolute progress and quality of knowledge) of the learning process during studying the vocational module "Control and metrological provision of tools and automation systems". The obtained figures of the absolute progress are close to $80 \%$, which allows 
to speak about almost complete mastering of the learning material of the vocational module.

\section{Conclusions}

One of the main conditions for the successful preparation of students in accordance with the requirements of the new educational standards is the selection of new adapted teaching technologies that must satisfy not only a number of methodological requirements (conceptuality, systemic, efficiency, reproducibility, controllability), but also have such qualities as mobility, ability to change rapidly, so that every student of a vocational education institution learns not "anything and somehow" but with guaranteed success, which is significant in the context of shifting the emphasis on the student's interests, as well as the transition from passive mastering of knowledge to active process of formation of skills of their application in the process of vital activity.

In turn, the technological development of learning materials that determine the actions of the teacher from the goals to the assessment of the results, allow the teacher of any level to achieve the adjusted results.

It should be emphasized that the development of a specific pedagogical technology is a design process, consisting of successive steps [14]:

1) selection of the content of learning (provided for by the learning plan and program);

2) selection of priority goals (for which the teacher should be oriented);

3) selection of technology (focused on a complex of goals or for one priority goal);

4) development of technology of teaching. At the same time, it is impossible to take the creation (development) of individual methods, ways or means of teaching for the new technology of education.

The selection of teaching technology is determined by a number of factors: the priority of the goals of education; specificity of the content of the learning material; feature of the membership of students; level of development of the technical equipment of the educational process.

In this research, the selection of pedagogical technologies was materialized on the basis of the principle of complete mastering of educa- 
tional material, which provides for the achievement of the established level of cognitive activity for each training course. It was also found that in the domestic practice the following methods for determining numerical characteristics are used to assess the integrative qualities of students (knowledge, skills, practical skills and competences) (see Figure 8): methodology of formation of universal learning actions, end-to-end technology of assessing learning results (which allows to calculate the numerical index of the development of interested competence), method of prolonged assessment (rating system, which reflects the indicator of the student's progress rating in points), as well as methodology for calculating absolute progress and the indicator of the complete mastering of the educational material (percentage of the quality of knowledge).

\begin{tabular}{|c|c|c|}
\hline \multicolumn{2}{|c|}{ End-to-end technology of assessing learning results } & $\begin{array}{l}\text { Indicator of the } \\
\text { complete } \\
\text { assimilation of the } \\
\text { educational material }\end{array}$ \\
\hline $\begin{array}{l}\text { Methodology of formation } \\
\text { of universal learning actions }\end{array}$ & $\begin{array}{l}\text { Method of prolonged } \\
\text { assessment (rating system) }\end{array}$ & IV course \\
\cline { 2 - 3 } & II - IV course &
\end{tabular}

Fig. 8. Methods and technologies of assessment of student's progress results in form of numerical characteristics

It is determined that end-to-end technology and rating system allow to obtain a more objective quantitative assessment of students' academic progress, depending on the learning and economic goals assigned to the teacher [15]. In general, the methods and technologies for assessing students' learning results (Figure 7) are positively reflected in the "cognitive activity of students, form their responsibility for the result of their own activities and, importantly, allow to reduce the formality of control [16], which is consistent with the requirements of educational standards of the third generation".

\section{Сиисок литературь}

1. Михайленко О.И. Общая педагогика. Раздел дидактика. URL: http:// kpip.kbsu.ru/pd/index.html\#did_11 (дата обращения: 22.02.2017).

2. Мухаметзянова Л.Ю. Методологические конструкты технологического обеспечения педагогического процесса / Л.Ю. Мухаметзянова, А.Р. Камалеева // Actualcience. 2016. Т.2. №2. С. 21-23. 
3. Шигапова Н.В. Выход на технологический уровень проектирования педагогами учебного процесса как альтернатива формальному традиционному обучению / Н.В. Шигапова, А.Р. Камалеева, С.Ю. Грузкова // Вестник Челябинского государственного педагогического университета. 2016. № 2. С. 40-46.

4. Мухаметзянова Ф.Ш. Организация взаимодействия субъектов образовательного процесса при использовании платформ дистанционного обучения / Ф.Ш. Мухаметзянова, А.Р. Камалеева, С.Ю. Грузкова, Р.Р. Хадиуллина // Открытое образование. 2016. № 3. С. 36-42.

5. Русскова О.Б. Диагностический инструментарий оценивания результатов обучения в системе профессионального образования / О.Б. Русскова, А.Р. Камалеева, С.Ю. Грузкова // Вестник Томского государственного педагогического университета. 2014. №11 (152). C. $134-139$.

6. Грузкова С.Ю. Роль технических средств обучения в современном педагогическом процессе / С.Ю. Грузкова, А.Р. Камалеева // Информация и образование: границы коммуникаций INFO 14: сборник научных трудов. Горно-Алтайск: РИО ГАГУ. 2014. № 6 (14). Раздел 8. 411 с. С. 346-348.

7. Альмеева Л.А. Особенности применения информационных технологий в общеобразовательных дисциплинах СПО / А.Л. Альмеева, С.Ю. Грузкова, М.Л. Грунис // Современные проблемы инновационного развития науки: сборник статей международной научно-практической конференции. Уфа: МЦИИ «ОМЕГА САЙНС». В 3 ч., Ч2. 2016. 221 c. С. 93-97.

8. Камалеева А.Р. Концепция формирования самообразовательных умений, навыков и основных естественно-научных компетенций учащейся молодежи в процессе непрерывного естественно-научного образования // Вестник Томского государственного педагогического университета. 2012. № 2 (117). С. 139-146.

9. Камалеева А.Р. Научно-методическая система формирования основных естественнонаучных компетенций учащейся молодежи: Автореф. дис. ... д-ра пед. наук. Москва, 2012.

10. Мухаметзянова Ф.Ш. Сквозная технология оценивания результатов обучения студентов в системе профессионального образова- 
ния / Ф.Ш. Мухаметзянова, А.Р. Камалеева, О.Б. Русскова // Проблемы современного педагогического образования. 2016. Вып. 52. Ч.3. С. $173-183$.

11. Шигапова Н.В. Влияние отбора технологий реализации естественнонаучной и профессиональной подготовки на результативность учебного процесса / Н.В. Шигапова, А.Р. Камалеева, С.Ю. Грузкова, О.В. Софинская // Recent trend in Science and Technology management: 7-я международная конференция. Лондон "SCIEURO", 2017. T 2. 244 c. C.137-147.

12. Софинская О.В. Мониторинг качества знаний студентов ссуз в условиях реализации новых образовательных стандартов / О.В. Софинская, С.Ю. Грузкова // Межд. научн. журнал. «Путь науки», 2014. №2 (2). С. 74-78.

13. Грузкова С.Ю. Альтернативные традиционным методы качественного контроля успешности студентов ссуз в условия реализации ФГОС СПО / Инновационная стратегия развития фундаментальных и прикладных научных исследований: опыт прошлого - взгляд в будущее: сборник научных статей по итогам Международной научно-практической конференции. СПб.: Изд-во «КультИнформПресс». 2016. С. 67-69.

14. Камалеева А.Р. Взгляд на технологизацию учебно-воспитательного процесса в условиях реализации новых образовательных стандартов в системе СПО / А.Р. Камалеева, С.Ю. Грузкова // Современная педагогическая наука и образование в россии: наследие, традиции, прогнозы: сборник материалов международной научно-практической конференции / Под научной редакцией Ф.Ш. Мухаметзяновой, Казань: ФГБНУ «ИППСП», 2016. 305 с. C. 106-114.

15.Русскова О.Б. Контроль практико-ориентированного обучения студентов в организациях среднего профессионального образования (на примере дисциплин естественнонаучного и профессионального циклов) / О.Б. Русскова, С.Ю. Грузкова // Научно-практический журнал «Заметки ученого». Ростов на Дону: «ПРИОРИТЕТ», 2016. №6. 78 c. С. 16-21. 
16. Грязнов А.Н. Психопедагогическое исследование эмоциональных и оценочных психических состояний студентов, подверженых аддикциям / А.Н. Грязнов, С.Ю. Грузкова, Э.С. Шарафиев, Е.А. Чеверикина, Л.Ю. Мухаметзянова, А.Р. Камалеева, Р.Х. Гильмеева // Международный журнал "Environmental and Science Education". 2016. Т.11. Выпуск 15. С. 8343-8349.

\section{References}

1. Mikhaylenko O.I. Obshchaya pedagogika [General pedagogics. Section didactics]. http://kpip.kbsu.ru/pd/index.html\#did_11 (date of the address: 22.02.2017).

2. Mukhametzyanova L.Yu., Kamaleeva A.R. Actualcience [Actualcience]. 2016. V.2. No.2, pp. 21-23.

3. Shigapova N.V., Kamaleeva A.R., Gruzkova S.Yu. Vestnik Chelyabinskogo gosudarstvennogo pedagogicheskogo universiteta [Bulletin of the Chelyabinsk state pedagogical university]. 2016. No. 2, pp. 40-46.

4. Mukhametzyanova F.Sh., Kamaleeva A.R., Gruzkova S.Yu., Hadiullina R.R. Otkrytoe obrazovanie [Open education]. 2016. No. 3, pp. 36-42.

5. Russkova O.B., Kamaleeva A.R., Gruzkova S.Yu. Vestnik Tomskogo gosudarstvennogo pedagogicheskogo universiteta [Bulletin of the Tomsk state pedagogical university]. 2014. No. 11 (152), pp. 134-139.

6. Gruzkova S.Yu., Kamaleeva A.R. Informatsiya i obrazovanie: granitsy kommunikatsiy INFO 14 [Information and education: borders of communications of INFO 14]. Gorno-Altaysk, 2014. No. 6 (14). Section 8. 411 p., pp. 346-348.

7. Almeeva L.A., Gruzkova S.Yu., Grunis M.L. Sovremennye problemy innovatsionnogo razvitiya nauki [Modern problems of innovative development of science]. Ufa, 2016. In 3 h, Ch2. 221 p., pp. 93-97.

8. Kamaleeva A.R. Vestnik Tomskogo gosudarstvennogo pedagogicheskogo universiteta [Bulletin of the Tomsk state pedagogical university]. 2012. No. 2 (117), pp. 139-146.

9. Kamaleeva A.R. Avtoref. dis. ... d-ra ped. nauk. [Abstract of the thesis of the doctor of pedagogical sciences]. Moscow, 2012. 
10. Mukhametzyanova F.Sh., Kamaleeva A.R., Russkova O.B. Problemy sovremennogo pedagogicheskogo obrazovaniya [Problems of modern pedagogical education]. 2016. Issue 52. Ch.3, pp. 173-183.

11. Shigapova N.V., Kamaleeva A.R., Gruzkova S.Yu., Sofinskaya O.V. [Recent trend in Science and Technology management], by SCIEURO in London, 2017. V2. 244 p. , pp. 137-147.

12. Sofinskaya O.V., Gruzkova S.Yu. Mezhdunarodnyy nauchnyy zhurnal «Put' nauki» [International scientific magazine "Way of Science"]. 2014. No. 2 (2), pp. 74-78.

13. Gruzkova S.Yu. Innovatsionnaya strategiya razvitiya fundamental'nykh i prikladnykh nauchnykh issledovaniy: opyt proshlogo - vzglyad v budushchee [Innovative strategy of the development of fundamental and economic scientific research: the experience of the past - a look into the future]. St. Petersburg, 2016, pp. 67-69.

14. Kamaleeva A.R., Gruzkova S.Yu. Sovremennaya pedagogicheskaya nauka i obrazovanie v rossii: nasledie, traditsii, prognozy [Modern pedagogical science and education in Russia: heritage, traditions, prognosis] / Mukhametzyanova F.Sh. (publ.). Kazan, 2016, pp. 106-114.

15. Russkova O.B., Gruzkova S.Yu. Nauchno-prakticheskiy zhurnal «Zametki uchenogo» [Scientific and practical magazine "Scientist's Notes"]. Rostov to Dona, 2016. No. 6. 78 p., pp. 16-21.

16. Gryaznov A.N., Gruzkova S.Yu., Sharafiev Ed.S., Cheverikina E.A., Mukhametzyanova L.Yu., Kamaleeva A.R., Gilmeeva R.Kh. Mezhdunarodnyy zhurnal "Environmental and Science Education" [The International Journal of (IJESE)], 2016. Volume 11. Issue 15, pp. 83438349 .

\section{ДАННЫЕ ОБ АВТОРАХ}

Камалеева Алсу Рауфовна, ведущий научный сотрудник, доктор педагогических наук, доцент, профессор РАЕ ФГБНУ «Институт педагогики, психологии и соичиальных проблем»

ул. Исаева, 12, г. Казань, 420039, Российская Федеращия kamaleyeva_kazan@mail.ru 
Грузкова Светлана Юрьевна, старший научный сотрудник, кандидат технических наук,

ФГБНУ «Институт педагогики, психологии и сочиальных проблем»

ул. Исаева, 12, г. Казань, 420039, Российская Федераиия svetlana81079@mail.ru

Шигапова Наталья Вячеславовна, старший научный сотрудник, кандидат педагогических наук, профессор РАЕ ФГБНУ «Институт педагогики, психологии и социальных проблем»

ул. Исаева, 12, г. Казань, 420039, Российская Федераџия zamdekan74@mail.ru

\section{DATA ABOUT THE AUTHORS}

Kamaleeva Alsu Raufovna, Leading Researcher, Doctor of Pedagogic Sciences, Docent, Professor of the RAE Institute of Pedagogics, Psychology and Social Issues 12, Isaev str., Kazan, post code 420039, Russian Federation kamaleyeva_kazan@mail.ru

Gruzkova Svetlana Yur'evna, Senior Researcher, Candidate of Engineering Sciences

Institute of Pedagogics, Psychology and Social Issues 12, Isaev str., Kazan, post code 420039, Russian Federation svetlana81079@mail.ru SPIN-code: 7085-6661

Shigapova Natal'ya Vyacheslavovna, Senior Researcher, Candidate of Pedagogic Sciences, Professor of the RAE Institute of Pedagogics, Psychology and Social Issues 12, Isaev str., Kazan, post code 420039, Russian Federation zamdekan74@mail.ru 